\title{
EXISTENCE RESULTS FOR A NONLINEAR FRACTIONAL DIFFERENTIAL EQUATIONS WITH INTEGRAL BOUNDARY CONDITIONS ON THE HALF-LINE
}

\author{
ABDElHAMID BENMEZAi AND ABDELKADER SAADI
}

\begin{abstract}
By means of nonlinear alternative theorem of Leray-Schauder, some new results on the existence of positive solutions for a nonlinear fractional differential equations with integral boundary conditions on unbounded domain are established. The paper concludes with an illustrative example.
\end{abstract}

Mathematics subject classification (2010): 26A33, 34B18, 34B27.

Keywords and phrases: Riemann-Liouville fractional derivatives, unbounded domain, positive solutions, nonlinear alternative theorem of Leray-Schauder.

\section{REFERENCES}

[1] R. P. Agarwal, M. Meehan, And D. O'Regan, Fixed Point Theory and Applications, 141, Cambridge University Press, Cambridge, UK, (2001).

[2] C. BAI, Triple positive solutions for a boundary value problem of nonlinear fractional differential equation, E. J. Qualitative Theory of Diff.Equ., 24, (2008) 1-10.

[3] C. BAI, Positive solutions for nonlinear fractional differential equations with coefficient that changes sign, Nonlinear Analysis., 64, (2006), 677-685.

[4] Z. BAI, H. LÜ, Positive solutions for a boundary value problem of nonlinear fractional differential equations, J. Math. Anal. Appl., 311, (2005), 495-505.

[5] M. Benchohra, J. Henderson, S. K. Ntoyuas, A. Ouahab, Existence results for fractional order functional differential equations with infinite delay, J. Math. Anal. Appl., 338, (2008), 13401350.

[6] D. Delbosco, L. Rodino, Existence and uniqueness for a nonlinear fractional differential equation, J. Math. Anal. Appl., 204, (1996) 609-625.

[7] D. Guo, V. Lakshmikantham, Nonlinear Problems in Abstract Cone, Academic Press, Saniego, 1988.

[8] W. JiANG, Solvability for fractional differential equations atresonance on the half line, Applied Mathematics and Computation., 61, (2014), 90-99.

[9] A. A. Kilbas, H. M. SRivastava, J. J. Trujillo, Theory and Applications of Fractional Differential Equations, North-Holland Mathematics Studies, 204. Elsevier science B. V., Amsterdam, 2006.

[10] M. A. KRasnosel'skiI, Topological Methods in the Theory on Nonlinear Integral Equations, (English) Translated by A. H. Armstrong, A Pergamon Press Book, MacMillan, New York, 1964.

[11] S. LiANG, J. ZHANG, Existence of three positive solutions of m-point boundary value problems for some nonlinear fractional differential equations on an infinite interval, Computers and Mathematics with Applications., 61, (2011), 3343-3354.

[12] Y. LiU, Existence and unboundedness of positive solutions for singular boundary value problems on half-line, Applied Mathematics and Computation., 144, (2003), 543-556.

[13] Y. LiU, B. AhMAD, R.P. AGARWAL, Existence of solutions for a coupled system of nonlinear fractional differential equations with fractional boundary conditions on the half-line, Advances in Difference Equations., 2013, 46, (2013). 
[14] I. Podlubny, Fractional Differential Equations, Academic Press, San Diego, 1999.

[15] A. SAADI, M. BEnBACHIR, Positive solutions for three-point nonlinear fractional boundary value problems, E. J. Qualitative Theory of Diff. Equ., 3, (2011), 1-19.

[16] A. SaAdi, A. Benmezai, M. Benbachir, Positive solutions for three-point nonlinear fractional semi- positone boundary value problems, PanAmerican Mathematical Journal., 22, 4, (2012), 41-57.

[17] A. SAadi, A Benmezai, Positive solutions for three-point nonlinear singular semi- positone fractional boundary value problems, Journal of Advanced Research in Dynamical and Control Systems., 5, 1, (2013), 1-17.

[18] X.SU, S. ZHANG, Unbounded solutions to a boundary value problem of fractional order on the halfline, Computers and Mathematics with applications., 61, (2011), 1079-1087.

[19] L. Zhang, B. Ahmad, G, Wang, R. P. Agarwal, M. Al-Yami and W. Shammakh, Nonlocal integrodifferential boundary value problem for nonliear fractional differential equations on an unbounded domain, Abstract and Applied Analysis., Volume(2013), Article ID 813903, (2013), 5 page.

[20] G. WANG, A. CABADA AND L. ZHANG, An integral boundary value problem for nonlinear differential equations of fractional order on an unbounded domain, J. Integral Equations Appl., 26, 1, (2014), $117-129$. 